\title{
Pengaruh Kualitas Produk, Harga, dan Distribusi Terhadap Volume Penjualan ARB Bakery di Kelurahan Sukmajaya
}

\author{
Toto Widiarto ${ }^{1}$, Ema Hardiana² \\ 1'2 Universitas Indraprasta PGRI Jakarta
}

\begin{tabular}{|c|c|}
\hline ARTICLE INFO & ABSTRACT \\
\hline $\begin{array}{l}\text { Article History: } \\
\text { Received } 10 \text { September } 2021 \\
\text { Revised } 19 \text { November } 2021 \\
\text { Accepted } 17 \text { Desember } 2021 \\
\text { Published } 30 \text { Desember } 2021\end{array}$ & $\begin{array}{l}\text { ARB (Original New Flavor) Bakery is a fast-growing business in the food industry } \\
\text { sector, especially snacks made from wheat flour. Where this business must } \\
\text { always be able to keep up with the changes that occur along with the } \\
\text { development of an increasingly advanced business world. Including finding new } \\
\text { techniques, as well as ways to be able to increase the sales volume which is the } \\
\text { company's goal. However, on the one hand, the company has not been too }\end{array}$ \\
\hline $\begin{array}{l}\text { Keywords: } \\
\text { Quality of product; } \\
\text { Price; } \\
\text { Distribution; } \\
\text { Sales volume. }\end{array}$ & $\begin{array}{l}\text { focused on the development of marketing such as market research, especially } \\
\text { research related to the sale of ARB bread. The purpose of this research is to } \\
\text { determine whether product quality, price, and distribution significantly influence } \\
\text { the sales volume of ARB (Original New Flavor) Bakery in Sukmajaya urban } \\
\text { village. This research was conducted by giving questionnaires to } 20 \text { respondents. } \\
\text { The research method uses multiple linear regression analysis to determine the } \\
\text { effect of independent variables }(X) \text { in this case is product quality, price and } \\
\text { distribution to the dependent variable (Y) in this case is sales volume with the the } \\
\text { help of SPSS version } 27.00 \text { software. Based on the results and discussion it can } \\
\text { be concluded that simultaneously quality of product, price, and distribution have a } \\
\text { positive and significant effect on the sales volume of ARB (Original New Flavor) } \\
\text { Bakery in Sukmajaya urban village, it is obtained by the results of testing the } \\
\text { hypothesis that shows the value of } f \text { count }>f \text { table (10,175>3,246). And the test } \\
\text { results partially state that the variables of product quality, price, and distribution } \\
\text { have a positive and significant effect on the sales volume of ARB (Original New } \\
\text { Flavor) Bakery in Sukmajaya urban village with a value of } t \text { count>t table } \\
\text { (2,575>2,120). This is evidenced by the results of the } f \text { hypothesis test } \\
\text { simultaneously and partially of thypothesis test in data analysis. }\end{array}$ \\
\hline
\end{tabular}

Corresponding Author:

Toto Widiarto,

Email: totowidiarto72@gmail.com

How to Cite: Widiarto, T, Hardiana, E.(2021). Pengaruh kualitas produk, harga, dan distribusi terhadap volume penjualan ARB bakery di kelurahan sukmajaya. Sosio e-Kons, 13 (03), 175-189

\section{PENDAHULUAN}

Perkembangan dunia bisnis saat ini semakin pesat sejalan mengikuti perkembangan jaman yang semakin maju. Hal ini dapat ditunjukkan pada sektor bisnis baik dalam bidang usaha produksi maupun jasa. Maka pemasaran memiliki peran yang sangat penting dalam menunjang kemajuan usaha. Untuk itu perusahaan harus memiliki manajerial pemasaran yang baik untuk dapat memuaskan konsumen agar berdampak baik terhadap keberlangsungan usaha. Pernyataan tersebut didukung oleh (Kotler \& Keller, 2009) yang menyatakan bahwa, "Manajerial pemasaran berkaitan dengan proses perencanaan dan pelaksanaan konsepsi, penetapan harga, promosi, distribusi gagasan, barang dan jasa untuk mencapai pertukaran yang memuaskan tujuan individu dan organisasi." Selain itu para pengusaha terus berupaya agar dapat meningkatkan volume penjualan untuk mendapatkan keuntungan yang menjadi tujuan dari perusahaan. Hal ini sejalan dengan pendapat Kotler \& Keller 
(2000) yaitu "Untuk meningkatkan volume penjualan, upaya yang dilakukan perusahaan adalah menerapkan manajemen perusahaan yang baik melalui instrument pemasaran atau biasa disebut dengan bauran pemasaran yang terdiri dari product (produk), price (harga), place (tempat/saluran distribusi), dan promotion (promosi)." Dalam pengelolaan marketing mix/bauran pemasaran dapat dikatakan efektif apabila menyajikan produk yang dapat memenuhi kebutuhan dan keinginan konsumen, menerapkan harga dan syarat pembayaran produk tersebut sesuai dengan ketersediaan konsumen untuk membayar, mengusahakan produk-produk tersebut tersedia pada tempat-tempat yang memudahkan konsumen untuk membeli setiap saat, dan memberitahukan konsumen mengenai keberadaan produk di pasar secara terus menerus meyakinkan mereka bahwa produk tersebut dapat memberikan kepuasan yang optimal. Strategi yang harus dilakukan perusahaan dalam penyajian produk untuk dapat memenuhi kebutuhan konsumen adalah dengan memproduksi barang yang berkualitas dan mampu bersaing dengan produk-produk yang ada di pasaran. Kualitas produk merupakan penggerak kepuasan pelanggan yang pertama dan merupakan dimensi yang global. Oleh sebab itu, dalam melakukan strategi pengembangan produk perusahaan diharapkan memahami aspek dimensi yang digunakan konsumen dalam membedakan produk yang dijual suatu perusahaan dengan produk pesaing. Sehingga jika hal tersebut dilaksanakan maka dapat meningkatkan volume penjualan pada suatu perusahaan. Oleh karena itu suatu perusahaan penting sekali untuk memilih strategi dalam mempromosikan produknya agar dapat merebut pangsa pasar. Endaryono, B. T., \& Djuhartono, T. (2021).

Dalam bauran pemasaran strategi kualitas produk sangat berkaitan dengan strategi harga. Di mana strategi penerapan harga dan syarat pembayaran produk tersebut sesuai dengan ketersediaan konsumen untuk membayar. Harga merupakan salah satu isyarat yang digunakan konsumen dalam proses persepsi, di mana harga akan memengaruhi penilaian konsumen tentang suatu produk. Dalam menggunakan suatu produk atau jasa maka konsumen akan membandingkan antara biaya atau usaha yang dikeluarkan dengan manfaat atau keuntungan yang telah diperoleh konsumen sehingga tercipta nilai pelanggan. Hal ini sejalan dengan pendapat Woodall (dalam Senoaji, 2008), "Nilai untuk pelanggan atau Value for the Customer (VC) mencerminkan customer value itu sendiri, di mana menjelaskan mengenai apa yang diterima oleh konsumen dan juga apa yang dapat diberikan oleh konsumen." Hal tersebut berarti apabila barang yang diinginkan konsumen berkualitas tinggi maka tentunya konsumen bersedia untuk membayar mahal sebaliknya bila kebutuhan konsumen adalah barang yang berkualitas standar maka harga tergolong tidak terlalu mahal. Dalam penetapan harga perusahaan harus memperhatikan faktor-faktor yang memengaruhi harga, baik faktor secara langsung maupun tidak langsung. Selain itu hal di atas juga diperkuat oleh pendapat Kotler \& Keller (2007) yang mengatakan bahwa, "Kebijakan harga sangat menentukan dalam pemasaran sebuah produk, karena harga adalah satu-satunya unsur bauran pemasaran yang memberikan pendapatan bagi organisasi atau perusahaan." Jadi, tidak dapat dipungkiri bahwa harga merupakan suatu unsur penting, baik bagi perusahaan dalam memengaruhi konsumen maupun bagi perusahaan untuk bertahan dalam persaingan.

Di samping kualitas produk dan harga faktor yang tidak kalah pentingnya dalam memengaruhi volume tingkat penjualan adalah saluran distribusi. Pendapat ini didukung oleh David (2009) yang mengatakan bahwa, "Saluran distribusi merupakan perantara untuk memindahkan produk atau jasa dari produsen ke konsumen. Saluran distribusi merupakan suatu kegiatan penting untuk memperlancar pengiriman barang sehingga penjualan bisa tercapai sesuai target yang diinginkan." Sebuah perusahaan harus pandai dalam melakukan penyebaran produknya. Perusahaan harus dapat melihat peluang pasar untuk mendistribusikan produknya, tidak hanya pasar lokal tetapi juga nasional. Semua itu dilakukan agar produk perusahaan dapat dijangkau semua kalangan konsumen. Selain itu menurut Umam et al. (2014), adapun fungsi saluran distribusi meliputi; mengumpulkan informasi yang diperlukan untuk perencanaan dan memudahkan pertukaran, mengembangkan dan menyebarkan komunikasi mengenai tawaran, melakukan pencarian dan berkomunikasi dengan calon pembeli, membentuk dan menyesuaikan tawaran dengan kebutuhan pembeli, mengadakan negosiasi untuk mencapai 
kesepakatan atas harga dan ketentuan lainnya mengenai tawaran agar perpindahan pemilikan dapat terjadi, melaksanakan pengangkutan dan penyimpanan produk, mengatur distribusi dana untuk menutup biaya saluran distribusi dan menerima risiko dalam hubungan dengan pelaksanaan pekerjaan saluran pemasaran.

Demikian pula halnya dengan pemasaran pada ARB (Asli Rasa Baru) Bakery di Kelurahan Sukmajaya yang terus berupaya dalam meningkatkan volume penjualan. Guna meningkatkan volume penjualannya usaha ini sangat memerlukan langkah-langkah atau strategi pemasaran yang tepat. ARB (Asli Rasa Baru) Bakery diharapkan agar dapat efektif dalam melakukan penjualan produknya serta berupaya untuk mampu melihat peluang pasar agar dapat mendistribusikan produknya. Di samping hal itu ARB (Asli Rasa Baru) Bakery juga diharapkan agar pandai dalam menentukan harga jual, karena industri ini mendistribusikan produknya ke berbagai warung-warung setempat sehingga hal ini akan memengaruhi harga jual. Semua strategi pemasaran ini diupayakan agar produk ARB (Asli Rasa Baru) Bakery dapat dijangkau semua kalangan konsumen khususnya di Kelurahan Sukmajaya Depok.

Menurut data hasil penjualan ARB (Asli Rasa Baru) Bakery periode tahun 2020 sebagian besar tidak dapat mencapai target yang telah ditentukan, hal tersebut menyebabkan terjadinya penurunan volume penjualan yang didukung dengan data penjualan selama 3 bulan terakhir yaitu dari bulan agustus sampai bulan oktober sebanyak 1000 pcs roti yang tidak mencapai target penjualan.

Untuk itu ARB (Asli Rasa Baru) Bakery harus dapat menerapkan strategi pemasaran yang efektif, salah satunya dapat dilihat dari stabilitas tingkat penjualan atau akan lebih baik bila dapat meningkat dari tahun ke tahun sesuai dengan kuantitas/kualitas produk yang mampu diproduksi oleh perusahaan. Maka pihak manajemen harus membuat suatu strategi yang mampu memanfaatkan berbagai kesempatan yang ada dan berusaha mengurangi dampak ancaman menjadi suatu kesempatan.

Maka dari itu berdasarkan permasalahan yang terjadi pada penurunan volume penjualan ARB (Asli Rasa Baru) Bakery, serta berdasarkan kajian teori pendukung mengenai faktor-faktor pengaruh penunjang volume penjualan yang telah dikemukakan oleh berbagai ahli melalui jurnal penelitian di atas, mendorong penulis untuk meneliti mengenai "Pengaruh Kualitas Produk, Harga dan Distribusi terhadap Volume Penjualan ARB Bakery di Kelurahan Sukmajaya.

\section{METODE}

Penelitian ini menggunakan metode analisis regresi linier berganda dengan pendekatan deskriptif kuantitatif. "Analisis regresi linier berganda ini digunakan untuk mengetahui besarnya pengaruh dua atau lebih variabel bebas dengan cara bersama terhadap satu variabel terikat, analisis regresi linier berganda adalah hubungan secara linier antara dua atau lebih variabel independen $(X 1$, $\mathrm{X} 2, \mathrm{X} 3 \ldots . . . \mathrm{Xn})$ dengan variabel

dependen (Y)" Sugiyono (2017). Analisis regresi linier berganda digunakan untuk mengetahui pengaruh dengan menentukan nilai $Y$ (sebagai variabel terikat dalam penelitian ini yaitu volume penjualan) dan untuk menaksir nilai-nilai yang berhubungan dengan $X$ (sebagai variabel bebas dalam penelitian ini yaitu kualitas produk, harga, dan distribusi).

Populasi dalam penelitian ini adalah 100 pelanggan yang secara rutin setiap bulannya membeli dan mengonsumsi roti ARB (Asli Rasa Baru) Bakery yang ada di Kelurahan Sukmajaya. Dengan populasi sebanyak 100 konsumen yang membeli produk roti secara rutin setiap bulannya, kemudian berdasarkan rumus Slovin diperoleh jumlah sampel sebanyak 20 konsumen menggunakan standard error $20 \%$. Adapun penentuan sampel yang terpilih dalam penelitian ini menggunakan teknik nonprobability sampling di mana setiap elemen populasi tidak memiliki peluang atau probabilitas atau kesempatan yang sama sebagai sampel. Prosedur non-probability sampling yang dilakukan adalah purposive sampling, di mana "teknik pengambilan sampel untuk tujuan tertentu saja dan hal ini juga dimaksudkan untuk menyesuaikan permasalahan dan tujuan penelitian" (Rahmayanti, 2010). 
Data yang digunakan dalam penelitian ini adalah data primer dan data sekunder. Data primer merupakan data yang diperoleh secara langsung dari subjek penelitian yaitu responden melalui kuesioner dan data sekunder merupakan data yang diperoleh secara tidak langsung baik lewat dokumen, buku-buku, literatur, penelitian terdahulu, internet, dan instansi yang berkaitan dengan penelitian ini. Pengambilan data dilakukan dengan pemberian angket atau kuesioner kepada 20 responden sesuai denga sampel yang telah ditentukan untuk mengetahui pengaruh kualitas produk, harga dan distribusi terhadap volume penjualan. Kemudian penulis mengolah data untuk mencari hubungan antara variabel bebas dan variabel terikat tersebut menggunakan bantuan software SPSS 27.00 For Windows dengan pengolahan data melalui rumus analisis regresi linier berganda, serta mempertimbangkan syarat uji asumsi klasik yang terdiri dari uji normalitas, uji multikolinieritas, uji heteroskedastisitas, dan korelasi. Adapun pengujian hipotesis yang digunakan adalah uji parsial $(t)$ dan uji simultan (f).

\section{HASIL DAN PEMBAHASAN}

\section{Hasil}

1. Uji Validitas

Uji validitas data yang didapatkan dari penyebaran angket terhadap 20 responden dengan level signifikansi 0,05 (5\%) uji dua pihak menggunakan bantuan software SPSS 27.00 for Windows. Berdasarkan analisa perhitungan dilakukan dengan jumlah sampel sebanyak $20(\mathrm{~N})$ dan level signifikansi $5 \%$ (a) maka dapat diketahui $\mathrm{df}=\mathrm{N}-2=20-2=18$, sehingga diperoleh nilai $r$ tabel sebesar 0,444 . Maka dari itu hasil uji validitas dari tiap variabel dapat dilihat dari tabel dibawah ini:

Tabel 1.

Rekapitulasi Hasil Uji Validitas Kualitas Produk (X1)

\begin{tabular}{cccc}
\hline No Item Pernyataan & $r$ hitung & $r$ tabel & Keterangan \\
\hline 1 & 0,584 & 0,444 & Valid \\
2 & 0,663 & 0,444 & Valid \\
3 & 0,470 & 0,444 & Valid \\
4 & 0,619 & 0,444 & Valid \\
5 & 0,637 & 0,444 & Valid \\
6 & 0,704 & 0,444 & Valid \\
7 & 0,758 & 0,444 & Valid \\
\hline
\end{tabular}

Sumber : Data diolah peneliti (2021)

Tabel 1. menunjukkan bahwa pengujian validitas di mana butir soal dianggap valid jika nilai $r$ hitung $>$ r tabel (Arikunto:2010). Maka dapat disimpulkan bahwa semua item pernyataan variabel kualitas produk $\left(\mathrm{X}_{1}\right)$ valid dan dapat digunakan untuk pengujian lebih lanjut.

Tabel 2.

Rekapitulasi Hasil Uji Validitas Harga (X2)

\begin{tabular}{clll}
\hline No Item Pernyataan & $r$ hitung & $r$ tabel & Keterangan \\
\hline 1 & 0,921 & 0,444 & Valid \\
2 & 0,925 & 0,444 & Valid \\
3 & 0,583 & 0,444 & Valid \\
4 & 0,836 & 0,444 & Valid \\
5 & 0,701 & 0,444 & Valid \\
\hline
\end{tabular}

Sumber : Data diolah peneliti (2021) 
Tabel 2. menunjukkan bahwa pengujian validitas di mana butir soal dianggap valid jika nilai $r$ hitung $>$ r tabel (Arikunto:2010). Maka dapat disimpulkan bahwa semua item pernyataan variabel harga (X2) valid dan dapat digunakan untuk pengujian lebih lanjut.

Tabel 3.

Rekapitulasi Hasil Uji Validitas Distribusi (X3)

\begin{tabular}{cccl}
\hline No Item Pernyataan & $r$ hitung & $r$ tabel & Keterangan \\
\hline 1 & 0,486 & 0,444 & Valid \\
2 & 0,568 & 0,444 & Valid \\
3 & 0,774 & 0,444 & Valid \\
4 & 0,732 & 0,444 & Valid \\
5 & 0,783 & 0,444 & Valid \\
6 & 0,479 & 0,444 & Valid \\
7 & 0,464 & 0,444 & Valid \\
\hline
\end{tabular}

Sumber : Data diolah peneliti (2021)

Tabel 3. menunjukkan bahwa pengujian validitas di mana butir soal dianggap valid jika nilai $r$ hitung $>r$ tabel (Arikunto:2010). Maka dapat disimpulkan bahwa semua item pernyataan variabel distribusi $\left(X_{3}\right)$ valid dan dapat digunakan untuk pengujian lebih lanjut.

Tabel 4.

Rekapitulasi Hasil Uji Validitas Volume Penjualan (Y)

\begin{tabular}{cccc}
\hline No Item Pernyataan & $r$ hitung & $r$ tabel & Keterangan \\
\hline 1 & 0,928 & 0,444 & Valid \\
2 & 0,936 & 0,444 & Valid \\
3 & 0,909 & 0,444 & Valid \\
\hline
\end{tabular}

Sumber : Data diolah peneliti (2021)

Tabel 4. menunjukkan bahwa pengujian validitas di mana butir soal dianggap valid jika nilai $r$ hitung $>$ r tabel (Arikunto:2010). Maka dapat disimpulkan bahwa semua item pernyataan variabel volume penjualan $(Y)$ valid dan dapat digunakan untuk pengujian lebih lanjut.

2. Uji Reliabilitas

Untuk pengujian reliabilitas dalam penelitian ini menggunakan analisis item yaitu mengkorelasikan skor item menggunakan rumus alpha atau Cronbach's Alpha. Maka dari itu untuk mempermudah perhitungannya peneliti menggunakan bantuan software SPSS Statistics 27.0 For Windows sebagai alat bantu hitung dalam analisis statistika. Adapun hasil perhitungannya sebagai berikut:

Tabel 5.

Rekapitulasi Hasil Uji Reliabilitas

\begin{tabular}{lll}
\hline Variabel & Cronbach's Alpha & Keterangan \\
\hline Kualitas Produk (X1) & 0,742 & Reliabel \\
Harga (X2) & 0,862 & Reliabel \\
Distribusi (X3) & 0,702 & Reliabel \\
Volume Penjualan (Y) & 0,910 & Reliabel \\
\hline
\end{tabular}

Sumber : Data diolah peneliti (2021)

Tabel 5. menunjukkan bahwa semua variabel memiliki angka Cronbach's Alpha>0,60. Hal ini menandakan bahwa semua variabel penelitian memiliki kuesioner yang handal atau reliabel (Ghozali, 2011). Dengan demikian dapat disimpulkan bahwa kuesioner yang digunakan untuk mengumpulkan data penelitian handal. 
3. Uji Asumsi Klasik

a. Hasil Pengujian Normalitas

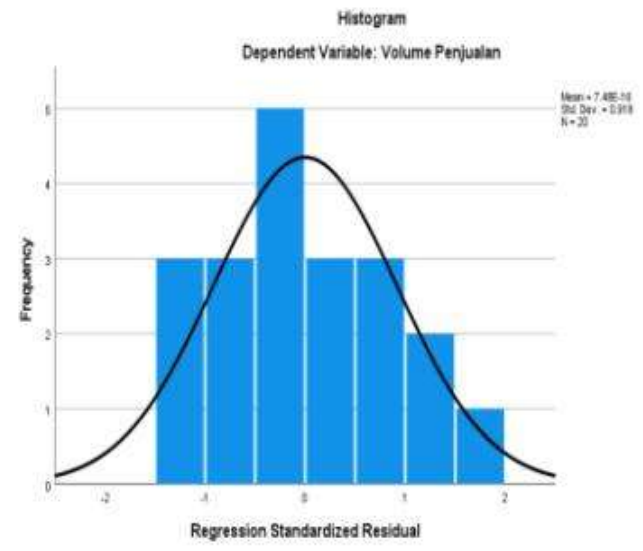

Sumber : Data diolah peneliti (2021)

Gambar 1. Hasil Pengujian Normalitas Histogram

Berdasarkan Gambar 1. di atas maka dapat disimpulkan bahwa data yang disajikan dalam penelitian berdistribusi normal, hal ini dapat dilihat pada gambar yang di mana data tersebut membentuk pola seperti lonceng dan tidak melenceng ke kiri maupun ke kanan. Selain itu grafik histogram P-P Plot juga digunakan peneliti untuk menguji normalitas data yaitu sebagai berikut:

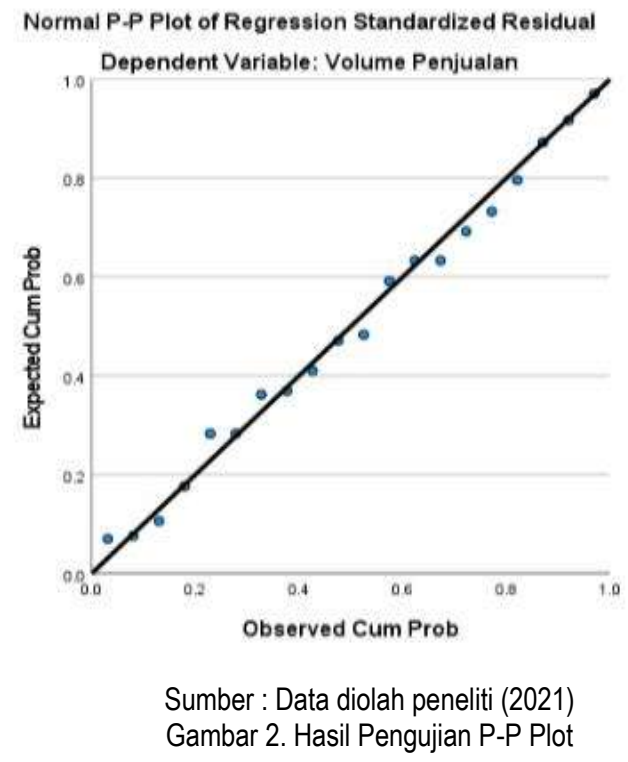

Berdasarkan Gambar 2. di atas maka dapat disimpulkan bahwa data yang disajikan dalam penelitian berdistribusi normal hal ini dapat dilihat pada gambar dari output SPSS di atas bahwa data menyebar di sekitar garis diagonal dan mengikuti arah garis diagonal atau juga dapat dikatakan bahwa grafik histogramnya menunjukkan pola distribusi normal. Maka model regresi memenuhi asumsi normalitas sehingga dapat dikatakan bahwa model regresi memenuhi asumsi normalitas. Lalu peneliti juga menggunakan uji statistik Kolmogrov Smirnov untuk menguji normalitas data yaitu sebagai berikut: 
Tabel 6.

Hasil Uji Statistik Kolmogrov Smirnov

One-Sample Kolmogorov-Smirnov Test

\begin{tabular}{lll}
\hline & One-Sample Kolmogorov-Smirnov Test \\
\hline \multirow{2}{*}{ Normal Parametersa,b } & & Unstandardized Residual \\
& Mean & 20 \\
\multirow{2}{*}{ Most Extreme Differences } & Std. Deviation & .0000000 \\
& Absolute & 1.34392349 \\
& Positive & .069 \\
Test Statistic & Negative & .069 \\
Asymp. Sig. (2-tailed)c & & -.066 \\
Sumber : Data diolah peneliti (2021) & & .069 \\
\end{tabular}

Berdasarkan Tabel 6. di atas hasil analisis metode one-sample kolmogrov-smirnov menunjukkan bahwa nilai kolmogrov-smirnov yaitu sebesar 0,069 dan nilai signifikansi 0,05 karena P-Value $=0,069>0,05$ hal ini memiliki arti bahwa data residual terdistribusi secara normal sehingga dapat digunakan dalam penelitian (Ghozali, 2011).

b. Hasil Pengujian Multikolinieritas

Tabel 7.

Hasil Uji Multikolinieritas

\begin{tabular}{|c|c|c|c|c|}
\hline \multicolumn{5}{|c|}{ Collinearity Statistics } \\
\hline & \multirow[t]{2}{*}{ Model } & & & \multirow[t]{2}{*}{ Keterangan } \\
\hline & & Tolerance & VIF & \\
\hline \multirow[t]{3}{*}{1} & Kualitas Produk & .401 & 2.492 & Tidak Multikolinieritas \\
\hline & Harga & .194 & 5.142 & Tidak Multikolinieritas \\
\hline & Distribusi & .128 & 7.823 & Tidak Multikolinieritas \\
\hline
\end{tabular}

Sumber : Data diolah peneliti (2021)

Berdasarkan Tabel 7. di atas menunjukkan bahwa semua variabel bebas dalam penelitian memiliki nilai tolerance $>0,01$ dan nilai $\mathrm{VIF}<10$. Sehingga dapat disimpulkan bahwa model regresi pada penelitian ini tidak terjadi multikolinieritas (Ghozali, 2011).

c. Hasil Pengujian Heteroskedastisitas

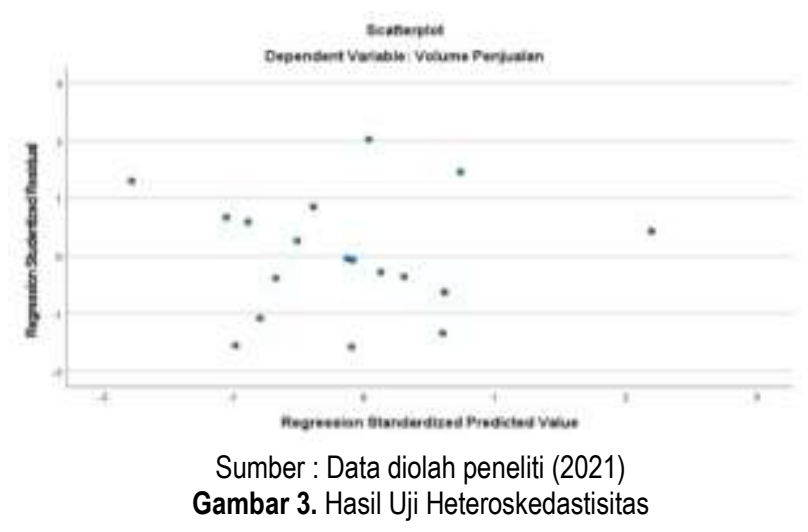

Berdasarkan Gambar 3. di atas, menunjukkan bahwa hasil tampak tidak berpola dan tidak beraturan di bawah dan di atas angka 0 (nol) pada sumbu Y. Sehingga dapat disimpulkan bahwa tidak terdapat gejala heteroskedastisitas (Ghozali, 2011). 
d. Hasil Pengujian Auto Korelasi

Tabel 8.

Hasil Uji Auto Korelasi

\begin{tabular}{cc}
\hline Koefisen & Nilai \\
\hline Durbin & \\
Watson & 1,476 \\
DI & 0,998 \\
Du & 1,676 \\
\hline
\end{tabular}

Sumber: Data diolah peneliti (2021)

Berdasarkan Tabel 8. di atas menunjukkan pengujian auto korelasi dengan uji DW (Durbin Watson) atau residual persamaan regresi. Maka dapat diperoleh angka d-hitung DW sebesar 1,476 untuk menguji gejala auto korelasi dengan membandingkan nilai d-teoritis dalam ttabel d-statistik. Dari nilai tabel statistik DW (Durbin Watson) dengan tingkat signifikansi 5\% (a) dan $\mathrm{k}=3$ dapat diperoleh nilai dl sebesar 0,998 dan du sebesar 1,676 karena hasil pengujiannya nilai adalah $\mathrm{dl}<\mathrm{d}<4$-du $(0,998<1,476<4-1,676)$ maka dapat disimpulkan bahwa data penelitian tidak terdapat gejala autokorelasi positif ataupun autokorelasi negatif untuk tingkat signifikansi $a=5 \%$ uji dua pihak.

4. Analisis Regresi Linier Berganda

Tabel 9.

Hasil Uji Regresi Linier Berganda

\begin{tabular}{cccc}
\hline \multicolumn{1}{c}{ Model } & \multicolumn{2}{c}{ Unstandardized Coefficients } \\
& $\mathrm{B}$ & Std. Error \\
\hline 1 & (Constant) & 10.192 & 3.645 \\
& Kualitas Produk & .276 & .107 \\
Harga & .426 & .183 \\
& Distribusi & .242 & .112 \\
\hline Sumber : Data diolah peneliti (2021) & &
\end{tabular}

Berdasarkan Tabel 9. di atas dapat disusun model persamaan regresi linier berganda untuk dapat mengukur arah dan kuatnya hubungan simultan variabel independen yaitu kualitas produk, harga, dan distribusi secara bersama-sama dengan variabel dependen yaitu volume penjualan yang diperoleh dengan melihat nilai $B$ pada Unstandardized Coefficients yaitu sebagai berikut: $Y=10,192+0,276+0,426+0,242+e$

Model persamaan regresi linier berganda tersebut mengandung arti:

a. Nilai konstanta (a) sebesar 10,192 yang berarti jika kualitas produk, harga, dan distribusi tidak mengalami perubahan atau sama dengan nol maka nilai volume penjualan sesuai dengan nilai konstanta sebesar 10,192.

b. Secara simultan adanya hubungan searah antara kualitas produk, harga, dan distribusi terhadap volume penjualan sebesar 0,315 . Hal ini berarti setiap ada peningkatan pada kualitas produk, harga, dan distribusi sebesar $1 \%$ maka volume penjualan juga akan meningkat sebesar 0,315 .

c. Koefisien regresi kualitas produk $\left(X_{1}\right)$ dari perhitungan linier berganda didapat nilai koefisien $\left(b_{1}\right)=0,276$. Tanda positif menyatakan bahwa adanya hubungan searah antara kualitas produk terhadap volume penjualan. Hal ini berarti setiap ada peningkatan pada kualitas produk $\left(X_{1}\right)$ sebesar 1\%, maka volume penjualan $(Y)$ juga akan meningkat sebesar 0,276 jika variabel independen lain dianggap konstan.

d. Koefisien regresi harga $\left(X_{2}\right)$ dari perhitungan linier berganda didapat nilai koefisien $\left(b_{2}\right)=0,426$. Tanda positif menyatakan bahwa adanya hubungan yang searah antara variabel harga terhadap volume penjualan. Hal ini berarti jika terjadi peningkatan harga $\left(X_{2}\right)$ sebesar $1 \%$ maka 
volume penjualan $(\mathrm{Y})$ akan meningkat sebesar 0,426 jika variabel independen lain dianggap konstan. Sehingga pengaruh variabel harga terhadap volume penjualan lebih dominan dibandingkan variabel independen lainnya.

e. Koefisien regresi distribusi $\left(X_{3}\right)$ dari perhitungan linier berganda didapat nilai koefisien $\left(b_{3}\right)=$ 0,242 . Tanda positif menyatakan bahwa adanya hubungan searah antara distribusi terhadap volume penjualan. Hal ini berarti setiap ada peningkatan pada distribusi $\left(X_{3}\right)$ sebesar $1 \%$, maka volume penjualan $(Y)$ juga akan meningkat sebesar 0,242 jika variabel independen lain dianggap konstan.

\section{Analisis Korelasi Sederhana dan Berganda}

a. Analisis Korelasi Sederhana

Analisis korelasi sederhana digunakan pada penelitian ini untuk dapat mengukur keeratan (kuat, lemah, atau tidak ada) hubungan antar variabel, dalam hal ini ditujukan untuk mengetahui hubungan antara variabel independen yaitu kualitas produk $\left(X_{1}=0,610\right)$, harga $\left(X_{2}\right.$ $=0,638)$ dan distribusi $\left(X_{3}=0,485\right)$ terhadap variabel dependen $(Y)$ yaitu volume penjualan. Adapun hasil perhitungan dan interpretasi yang didapatkan dengan bantuan SPSS 27.00 For Windows yaitu sebagai berikut:

Tabel 10.

Rekapitulasi Hasil Uji Korelasi Sederhana

\begin{tabular}{cccc}
\hline Variabel & Nilai r Secara Parsial & Korelasi & Interpretasi \\
\hline Kualitas Produk & 0,610 & Positif & Kuat \\
Harga & 0,638 & Positif & Kuat \\
Distribusi & 0,485 & Positif & Sedang \\
\hline
\end{tabular}

Sumber: Data diolah peneliti (2021)

Berdasarkan Tabel 10. dapat diketahui secara parsial bahwa nilai koefisien kualitas produk sebesar 0,610 berada pada interval $(0,60-0,79)$ yang menyatakan tingkat hubungan kuat, lalu nilai koefisien harga sebesar 0,638 berada pada interval $(0,60-0,79)$ yang menyatakan tingkat hubungan kuat, dan nilai koefisien distribusi sebesar 0,485 berada pada interval $(0,40-0,59)$ yang menyatakan tingkat hubungan sedang. Adapun hasil korelasi positif antara variabel kualitas produk, harga, dan distribusi terhadap variabel volume penjualan karena nilai koefisien berada pada posisi $r$ lebih besar dari 0 dan $r$ lebih kecil dari +1 atau $(0<r<+1)$

\section{b. Analisis Korelasi Berganda}

Analisis korelasi berganda digunakan pada penelitian ini untuk dapat mengukur arah dan kuatnya hubungan simultan variabel independen yaitu kualitas produk, harga, dan distribusi secara bersama-sama dengan variabel dependen yaitu volume penjualan. Adapun hasil perhitungan didapatkan dengan bantuan SPSS 27.00 yaitu sebagai berikut:

Tabel 11.

Hasil Uji Korelasi Berganda

\begin{tabular}{ccccc}
\hline \multicolumn{5}{c}{ Model Summaryb } \\
\hline Model & $\mathrm{R}$ & $\mathrm{R}$ Square & Adjusted R Square & $\begin{array}{c}\text { Std. Error of the } \\
\text { Estimate }\end{array}$ \\
\hline 1 & $.810 \mathrm{a}$ & .656 & .592 & 1.15205 \\
\hline
\end{tabular}

Sumber : Data diolah peneliti (2021) 
Berdasarkan Tabel 11. di atas dengan perhitungan Model Summary pada program SPSS 27.0 For Windows maka dapat diperoleh angka R sebagai hasil dari koefisien korelasi berganda yaitu sebesar 0,810 . Hal ini menunjukkan bahwa terjadi hubungan yang sangat kuat antara kualitas produk, harga, dan distribusi terhadap volume penjualan, hal ini dapat dilihat karena nilai $R$ berada pada interval $(0,80-1.00)$ yaitu sebesar 0,810 sehingga memiliki tingkat hubungan yang sangat kuat.

6. Koefisien Determinasi

Tabel 12.

Hasil Uji Koefisien Determinasi

\begin{tabular}{ccccc}
\hline \multicolumn{5}{c}{ Model Summaryb } \\
\hline Model & $\mathrm{R}$ & $\mathrm{R}$ Square & Adjusted R Square & $\begin{array}{c}\text { Std. Error of the } \\
\text { Estimate }\end{array}$ \\
\hline 1 & $.810 \mathrm{a}$ & .656 & .592 & 1.15205 \\
\hline Sumber : Data diolah peneliti (2021) & &
\end{tabular}

Berdasarkan Tabel 12. di atas maka dapat diperoleh koefisien determinasi untuk melihat seberapa besar kontribusi variabel independen yaitu kualitas produk, harga, dan distribusi, dalam menerangkan variabel dependen yaitu volume penjualan. Hal tersebut dapat dilihat pada hasil $R$ Square yaitu sebesar $65,6 \%$. Maka dari itu dapat disimpulkan bahwa kualitas produk, harga, dan distribusi berpengaruh terhadap volume penjualan sebesar $65,6 \%$ sedangkan sisanya sebesar $34,4 \%$ dipengaruhi oleh faktor-faktor lain yang tidak diikutsertakan dalam penelitian ini.

7. Pengujian Hipotesis

a. Uji Simultan (Uji F)

Uji $\mathrm{F}$ dalam penelitian ini digunakan untuk mengukur besarnya pengaruh variabel bebas yaitu kualitas produk, harga, dan distribusi secara bersama-sama terhadap variabel terikat yaitu volume penjualan. Adapun hasil perhitungan uji $\mathrm{F}$ didapatkan dengan bantuan program SPSS 27.00 For Windows melalui model Anova yaitu sebagai berikut:

Tabel 13.

Hasil Uji F (Simultan)

\begin{tabular}{ccccccc}
\hline & \multicolumn{5}{c}{ ANOVAa } \\
\hline & & Sum of & & Mean & & \\
& Model & Squares & Df & Square & F & Sig. \\
\hline 1 & Regression & 40.515 & 3 & 13.505 & 10.175 & $.001_{b}$ \\
& Residual & 21.235 & 16 & 1.327 & & \\
& Total & 61.750 & 19 & & & \\
\hline \multicolumn{2}{l}{ Sumber : Data diolah peneliti (2021) } & & & &
\end{tabular}

Berdasarkan Tabel 13. di atas maka dapat diperoleh nilai Fhitung sebesar 10,175 dengan nilai Sig sebesar 0,001 dan nilai $F$ tabel pada tingkat kesalahan $a=5 \%(0,05)$ uji dua pihak dengan jumlah sampel $n=20$, sehingga dapat diketahui derajat kebebasan $(d f)=(k-1),(n-$ $\mathrm{k})=(4-1),(20-4)=(3),(16)$ di mana $n$ adalah jumlah responden dan $\mathrm{k}$ adalah jumlah variabel, maka Ftabel didapatkan sebesar 3,246. Hal ini menunjukkan bahwa nilai $F$ hitung $>F$ tabel dan nilai Sig lebih kecil dari 0,05. Dengan demikian Ho ditolak dan H1 diterima. Artinya variabel bebas yang terdiri dari kualitas produk, harga, dan distribusi secara bersama-sama berpengaruh positif dan signifikan terhadap variabel terikat yaitu volume penjualan pada ARB (Asli Rasa Baru) Bakery di Kelurahan Sukmajaya. 
b. Uji Parsial (Uji T)

Uji T dalam penelitian ini digunakan untuk membuktikan pengaruh variabel bebas yaitu kualitas produk $\left(X_{1}=2,575\right)$, harga $\left(X_{2}=2,331\right)$, dan distribusi $\left(X_{3}=2,165\right)$ secara individual terhadap variabel terikat yaitu volume penjualan $(Y)$ dengan asumsi bahwa variabel yang lain tetap atau konstan. Adapun diketahui tingkat signifikansi $\alpha=5 \%(0,05)$ uji dua pihak dan jumlah sampel $n=20$, maka dari itu dapat diketahui nilai $d b=n-k=20-4=16$ di mana $n$ adalah jumlah responden dan $\mathrm{k}$ adalah jumlah variabel. Maka hasil diperoleh untuk $\mathrm{T}$ tabel sebesar 2,120. Adapun hasil perhitungan uji T didapatkan dengan bantuan program SPSS 27.0 For Windows yaitu sebagai berikut:

Tabel 14.

Hasil Uji T (Parsial)

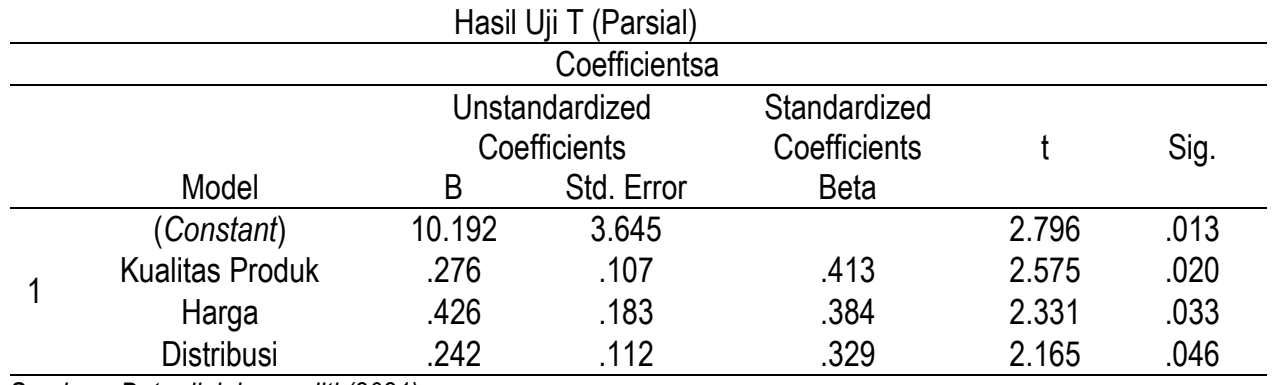

Sumber : Data diolah peneliti (2021)

Berdasarkan tabel 14. di atas dapat disimpulkan bahwa :

1) Pengaruh Kualitas Produk terhadap Volume Penjualan Hasil pengujian statistik kualitas produk terhadap volume penjualan menunjukkan nilai $T$ hitung $>T$ tabel $(2,575>2,120)$ dengan nilai Sig sebesar 0,020. Dengan demikian Ho ditolak dan $\mathrm{H} 1$ diterima. Artinya kualitas produk berpengaruh positif dan signifikan terhadap volume penjualan pada ARB (Asli Rasa Baru) Bakery di Kelurahan Sukmajaya.

2) Pengaruh Harga terhadap Volume Penjualan

Hasil pengujian statistik harga terhadap volume penjualan menunjukkan nilai Thitung $>$ Ttabel $(2,331>2,120)$ dengan nilai Sig sebesar 0,033. Dengan demikian Ho ditolak dan $\mathrm{H} 1$ diterima. Artinya harga berpengaruh positif dan signifikan terhadap volume penjualan pada ARB (Asli Rasa Baru) Bakery di Kelurahan Sukmajaya.

3) Pengaruh Distribusi terhadap Volume Penjualan Hasil pengujian statistik distribusi terhadap volume penjualan menunjukkan nilai $T$ hitung $>T$ tabel $(2,165>2,120)$ dengan nilai Sig sebesar 0,046. Dengan demikian Ho ditolak dan $\mathrm{H} 1$ diterima. Artinya distribusi

4) Berpengaruh positif dan signifikan terhadap volume penjualan pada ARB (Asli Rasa Baru) Bakery di Kelurahan Sukmajaya.

\section{Pembahasan}

Pada penelitian saat ini menyatakan bahwa kualitas produk berpengaruh positif terhadap volume penjualan dengan diperoleh hasil perhitungan korelasi $r=0,610$. Hal tersebut berarti terdapat pengaruh antara kualitas produk $\left(\mathrm{X}_{1}\right)$ terhadap volume penjualan $(\mathrm{Y})$ yang kuat dan positif karena hasil interval korelasi berada pada 0,60 - 0,79. Selain itu juga pada uji T secara parsial kualitas produk berpengaruh positif dan signifikan terhadap volume penjualan dengan diperoleh hasil $\mathrm{T}$ hitung $>\mathrm{T}$ tabel $(2,575>2,120)$. Hasil penelitian ini sama dengan penelitian yang dilakukan oleh Frendy $O$ Mokalu dan Altje Tumbel (2015) yang menunjukkan bahwa kualitas produk berpengaruh positif dan signifikan terhadap volume penjualan

Pada penelitian saat ini menyatakan bahwa harga berpengaruh positif terhadap volume penjualan dengan diperoleh hasil perhitungan korelasi $r=0,638$. Hal tersebut berarti terdapat pengaruh harga $\left(\mathrm{X}_{2}\right)$ terhadap volume penjualan $(\mathrm{Y})$ yang kuat dan positif karena hasil interval korelasi berada 
pada $0,60-0,79$. Selain itu juga pada uji $T$ secara parsial harga berpengaruh positif dan signifikan terhadap volume penjualan dengan diperoleh hasil $T$ hitung $>T$ tabel $(2,331>2,120)$. Hasil penelitian ini sejalan dengan penelitian yang dilakukan oleh lka Lis Mariatun (2017) yang menunjukkan bahwa harga berpengaruh positif dan signifikan terhadap volume penjualan.

Pada penelitian saat ini menyatakan bahwa distribusi berpengaruh positif terhadap volume penjualan dengan diperoleh hasil perhitungan korelasi $r=0,485$. Hal tersebut berarti terdapat pengaruh distribusi $\left(X_{3}\right)$ terhadap volume penjualan $(Y)$ yang sedang dan positif karena hasil interval korelasi berada pada 0,40-0,59. Selain itu juga pada uji T secara parsial distribusi berpengaruh positif dan signifikan terhadap volume penjualan dengan diperoleh hasil T hitung $>T$ tabel $(2,165>2,120)$.

Hal ini sejalan dengan teori yang dikemukakan oleh Pakpahan yang menyatakan bahwa faktor yang sangat penting dalam memengaruhi volume penjualan adalah saluran distribusi yang memiliki tujuan untuk melihat peluang pasar apakah dapat memberikan laba maksimum atau tidak. Secara umum mata rantai saluran distribusi yang semakin luas akan menimbulkan biaya yang lebih besar, tetapi semakin luas distribusi maka produk perusahaan akan semakin dikenal oleh masyarakat luas dan mendorong naiknya volume penjualan. Selain itu juga hasil penelitian ini sejalan dengan penelitian yang dilakukan oleh Untung Widodo (2020) yang menunjukkan bahwa distribusi berpengaruh positif dan signifikan terhadap volume penjualan

Selanjutnya hasil perhitungan koefisien determinasi yang diperoleh menyatakan bahwa kualitas produk, harga, dan distribusi berpengaruh terhadap volume penjualan sebesar $65,6 \%$ sedangkan sisanya sebesar $34,4 \%$ dipengaruhi oleh faktor-faktor lain yang tidak diikutsertakan dalam penelitian ini.

Dari hasil perhitungan secara parsial pada uji hipotesis T sudah dijelaskan pada interpretasi tiap variabel di atas bahwa semua variabel bebas yaitu kualitas produk, harga, dan distribusi berpengaruh positif dan signifikan terhadap variabel terikat yaitu volume penjualan dengan diperoleh hasil T hitung $>T$ tabel maka dapat dikatakan bahwa Ho ditolak dan $\mathrm{H} 1$ diterima pada taraf signifikansi $5 \%$ uji dua pihak.

Selain itu hasil perhitungan secara simultan pada uji $F$ diperoleh hasil $F$ hitung $>F$ tabel $(10,175>3,246)$ maka Ho ditolak dan $\mathrm{H} 1$ diterima pada taraf signifikansi $5 \%$ uji dua pihak. Jadi dapat disimpulkan bahwa kualitas produk, harga, dan distribusi secara bersama-sama berpengaruh positif dan signifikan terhadap volume penjualan.

Tesis pengujian $\mathrm{Ho}$ diterima dan $\mathrm{H} 1$ ditolak yang menyatakan bahwa tidak ada pengaruh antara variabel kualitas produk, harga, dan distribusi terhadap volume penjualan. Sedangkan tesis pengujian $\mathrm{Ho}$ ditolak dan $\mathrm{H} 1$ diterima yang menyatakan bahwa ada pengaruh antara variabel kualitas produk, harga, dan distribusi terhadap volume penjualan.

Maka dari itu berdasarkan hasil penelitian di atas dapat dikatakan, jika produk roti ARB Bakery mempertahankan serta mengembangkan aspek dari kualitas produk, harga maupun distribusi maka akan lebih memungkinkan pula terjadinya peningkatan volume penjualan pada roti ARB Bakery, hal ini dapat dilihat dari mayoritas jawaban responden mengenai pernyataan kualitas produk, harga, dan distribusi pada kuesioner sangat baik serta sesuai dengan kebutuhan dan keinginan konsumen, sehingga jika sudah seperti itu pihak perusahaan dapat melakukan pengembangan lagi pada usahanya agar volume penjualan terus meningkat secara stabil dan tidak menurun.

\section{SIMPULAN DAN SARAN}

\section{Simpulan}

Berdasarkan rumusan masalah dan tujuan penelitian, simpulan dari penelitian ini adalah:

1. Analisis Regresi Linier Berganda

Hasil uji analisis regresi linier berganda menyatakan bahwa semua variabel independen yaitu kualitas produk, harga, dan distribusi secara simultan memiliki hubungan searah terhadap variabel dependen yaitu volume penjualan dengan nilai sebesar 0,315 . Serta secara parsial 
memiliki hubungan yang searah terhadap volume penjualan dengan nilai pengaruh kualitas produk sebesar 0,276, harga sebesar 0,426, dan distribusi sebesar 0,242. Hal tersebut ditandai dengan hasil persamaan yang positif dengan bentuk persamaan yaitu : $Y=10,192+0,276+0,426+0,242$ + e.

2. Analisis Korelasi Sederhana dan Berganda

a. Pada hasil uji analisis korelasi sederhana didapatkan korelasi beserta interpretasi dari masing-masing variabel independen secara individual terhadap variabel dependen yaitu volume penjualan. Adapun hasil korelasi positif dari variabel kualitas produk yaitu sebesar $r=0,610$ dengan tingkat hubungan yang kuat. Lalu hasil korelasi positif dari variabel harga yaitu sebesar $r=0,636$ dengan tingkat hubungan yang kuat. Serta hasil korelasi positif dari variabel distribusi yaitu sebesar $r=0,485$ dengan tingkat hubungan yang sedang.

b. Pada hasil uji analisis korelasi berganda didapatkan hasil dari koefisien korelasi berganda yaitu sebesar $R=0,810$ sehingga memiliki tingkat hubungan yang sangat kuat antara masing-masing variabel independen yaitu kualitas produk, harga, dan distribusi secara simultan dalam memengaruhi variabel dependen yaitu volume penjualan.

3. Koefisien Determinasi

Pada hasil uji koefisien determinasi menyatakan bahwa kualitas produk, harga, dan distribusi berpengaruh terhadap volume penjualan sebesar $65,6 \%$ sedangkan sisanya sebesar $34,4 \%$ dipengaruhi oleh faktor-faktor lain yang tidak diikutsertakan dalam penelitian ini.

4. Uji Simultan (Uji F)

Pada hasil uji $\mathrm{F}$ secara simultan menyatakan bahwa variabel independen yang terdiri dari kualitas produk, harga, dan distribusi secara bersama-sama berpengaruh positif dan signifikan terhadap variabel dependen yaitu volume penjualan. Hal tersebut didukung oleh hasil perhitungan dengan tingkat signifikansi $5 \%$ uji dua pihak yang menunjukkan bahwa Fhitung $>$ Ftabel yaitu 10,175>3,246 dengan nilai Sig lebih kecil dari 0,05 yaitu sebesar 0,001 .

5. Uji Parsial (Uji T)

Pada hasil uji T secara parsial menyatakan bahwa masing-masing variabel independen memiliki pengaruh yang signifikan terhadap variabel dependen dengan tingkat signifikansi $5 \%$ uji dua pihak. Adapun diperoleh hasil uji parsial variabel kualitas produk yaitu Thitung $>$ Ttabel $(2,575>2,120)$ dengan nilai Sig lebih kecil dari 0,05 atau sebesar 0,020. Lalu hasil uji parsial variabel harga yaitu Thitung>Ttabel $(2,331>2,120)$ dengan nilai Sig lebih kecil dari 0,05 atau sebesar 0,033. Serta hasil uji parsial variabel distribusi yaitu Thitung $>$ Ttabel $(2,165>2,120)$ dengan nilai Sig lebih kecil dari 0,05 atau sebesar 0,046

\section{Saran}

Berdasarkan hasil penelitian dan simpulan yang telah disajikan, saran dari penelitian ini adalah:

1. Bagi Perusahaan (Pabrik Roti ARB (Asli Rasa Baru) Bakery)

a. Perusahaan harus mempertahankan bahkan meningkatkan kualitas produk yang telah diberikan karena persepsi konsumen mengenai kualitas produk pada roti sangatlah positif. Hal ini dapat dilihat dari banyaknya konsumen yang merasa terpuaskan dengan kualitas produk roti sehingga dapat memenuhi kebutuhan dan keinginan konsumen dalam mengonsumsi produk roti ARB (Asli Rasa Baru) Bakery.

b. Pada harga roti, sebaiknya perusahaan harus dapat terus mengembangkan strategi penetapan tingkat harga yang ditawarkan kepada konsumen karena persepsi konsumen mengenai harga pada produk roti ARB (Asli Rasa Baru) Bakery sangat baik. Maka dari itu sebaiknya perusahaan dapat mempertahankan dan mengembangkan lagi mengenai harga yang sesuai dengan produk roti yang dijual dengan daya beli konsumen.

2. Pada distribusi produk roti, sebaiknya perusahaan lebih memperketat dan meningkatkan lagi pendistribusian produknya dengan melihat peluang pasar agar distribusi produk tepat sasaran sehingga terus dapat meningkatkan volume penjualan. Selain itu perusahaan perlu lebih cekatan lagi melakukan pendistribusian produk agar para konsumen tidak menunggu produk roti ARB (Asli Rasa Baru) Bakery dalam waktu yang cukup lama lagi untuk dapat mengonsumsinya, karena persepsi konsumen mengenai distribusi produk pada produk roti ARB (Asli Rasa Baru) Bakery sudah cukup baik. 


\section{Bagi Konsumen}

Disarankan bagi konsumen untuk dapat lebih detail lagi dalam memilih setiap produk yang akan dikonsumsi agar hasil yang didapatkan sesuai dengan harapan, dan jangan pula ragu untuk melayangkan complain apabila mendapatkan ketidaksesuaian sebagai masukan untuk perusahaan sehingga dapat dievaluasi. Selain itu jadilah konsumen yang bijaksana yang mencari informasi mengenai produk sebelum dikonsumsi hal tersebut dapat dicapai dengan melakukan konsultasi pada pihak yang terpercaya.

4. Bagi Peneliti Selanjutnya

Untuk dapat mengembangkan hasil penelitian agar bisa menjadi prospek kajian berikutnya, sebaiknya untuk peneliti selanjutnya lebih mempertimbangkan lagi faktor-faktor lain yang dapat mempengaruhi volume penjualan diluar kualitas produk, harga maupun distribusi.

\section{REFERENCES/DAFTAR PUSTAKA}

Adi, C.P.A. (2018). Pengaruh kualitas produk, citra merek, harga promosi dan distribusi terhadap keputusan pembelian laptop merek Asus. (Skripsi). FEB Muhammadiyah University, Yogyakarta.

Agustina, L. dan Suprihartini, L. dan Kusasi, F. (2019). Manajemen. Pengaruh saluran distribusi, kualitas produk, harga dan promosi terhadap volume penjualan kue Bangkit di home industri Ummi Nurul 88 Kota Tanjungpinang, 1-15.

Ananingsih, T. dan Hasiholan, L.B. dan Wahyono, E.H. (2018). Ekonomi dan Bisnis. Pengaruh kualitas produk, promosi, harga dan saluran distribusi terhadap keputusan pembelian produk Johnson and Johnson Indonesia, 1-10.

Chalil, Z.F. (2010). Pemerataan Distribusi Kekayaan dalam Ekonomi Islam. Jakarta: Erlangga.

Daryanto. (2011). Manajemen Pemasaran. Bandung: PT. Sarana Tutorial Nurani Sejahtera.

Endaryono, B. T., \& Djuhartono, T. (2021). Pengaruh biaya promosi dan kebijakan penetapan harga terhadap peningkatan penjualan (Studi pada PT Granitoguna Building Ceramics). Sosio eKons, 13(1), 10-18.

Febriyanto, N.A. (2015). Pengaruh Pengembangan Produk Terhadap Volume Penjualan Pada Konveksi Busana Muslim Clothing Kendal. (Skripsi). Islam Negeri Walisongo University, Semarang.

Ghozali, I. (2016). Aplikasi Analisis Multivariete dengan Program IBM. SPSS 21. Semarang : Published Diponegoro University.

Hajar, I. (2010). Dasar-Dasar Metodologi Kualitatif dalam Pendidikan. Jakarta: Raja Grafindo Persada.

Herimanto. dan Winarno. (2016). IImu Sosial dan Budaya Dasar. Jakarta : Bumi Aksara. Karim, D. dan Sepang, J.L. dan Lumanauw, B. (2014). Ekonomi dan Bisnis. Marketing mix pengaruhnya terhadap volume penjualan pada PT. Manado Sejati Perkasa Group, 2(1), 421-430.

Kotler, P. dan Armstrong, G. (2010). Dasar-Dasar Pemasaran. Jakarta: Prenhalindo.

Kotler, P. dan Keller, K. L. (2010). Manajemen Pemasaran. Jakarta: Erlangga.

Kotler, P. dan Keller, K. L. (2010). Prinsip-Prinsip Pemasaran. Jakarta: Erlangga.

Lestari, M. (2019). Pengaruh kualitas produk, harga dan distribusi terhadap volume penjualan Gerabah. (Skripsi). Islam Negeri University, Mataram.

Limakrisna. (2011). Perilaku konsumen dan strategi pemasaran untuk memenangkan persaingan bisnis. Jakarta : Mitra Wacana Media.

Mariatun, I.L. (2016). IImu dan Pendidikan Ekonomi-Sosial. Pengaruh saluran distribusi, harga dan promosi terhadap volume penjualan pada home industri tempe putra KL Kecamatan Socah, 1(1), 31-45.

Mokalu, F.O. dan Tumbel, A. (2015). Ekonomi dan Bisnis. Pengaruh kualitas produk, harga dan distribusi terhadap volume penjualan roti Jordan CV. Minahasa Mantap Perkasa, 3(1), 254-265. 
Muchidin, D.J. (2016). Analisis pengaruh produk, harga, promosi dan tempat terhadap keputusan pembelian produk (studi pada PT Indosat Ooredoo). (Skripsi). Muhammadiyah University, Yogyakarta.

Muqorobin, A.J. (2016). Pengaruh harga, kualitas produk, dan saluran distribusi terhadap volume penjualan roti kacang di UD, Tidar. (Skripsi). Nusantara Persatuan Guru Republik Indonesia University, Kediri.

Nurcahyo, F. dan Wahyuati, A. (2016). IImu dan Riset Manajemen. Pengaruh bauran pemasaran terhadap volume penjualan pada restoran MC Donald's Delta Plaza Surabaya, 5 (4), 1-17.

Prastiwi, Q. (2019). Analisis strategi pemasaran dalam meningkatkan volume penjualan pada UMKM pabrik roti Alfaris Bakery Medan. (Skripsi). Muhammadiyah Universitas, Medan.

Puryono, M. (2019). Pengaruh kualitas produk, harga, promosi dan saluran distribusi terhadap volume penjualan produk Alumunium Sulfate di PT. Liku Telaga. (Skripsi). Muhammadiyah Universitas, Gresik.

Sangadji, M.E. dan Sopiah. (2013). Perilaku Konsumen. Yogyakarta: ANDI.

Sefudin, A. dan Prasetyono, H. dan Hapsari, S. (2018). Perilaku Organisasi. Jakarta: Mitra Abadi.

Sugiyono. (2017). Metode Penelitian Kuantitatif, Kualitatif dan R\&D Cetakan ke-25. Bandung: Alfabeta.

Sugiyono. (2015). Metode Penelitian Manajemen. Bandung : Alfabeta.

Sugiyono. (2011). Metode Penelitian Kuantitatif, Kualitatif dan R\&D. Bandung : Alfabeta. Supardi. (2013). Aplikasi Statistik Dalam Penelitian Konsep Statistika yang Lebih Komprehensif. Jakarta : Change Publication.

Swastha, B. (2012). Manajemen Pemasaran Modern. Yogyakarta: Liberty.

Syaleh, H. (2017). Ekonomi, Bisnis dan Akuntansi. Pengaruh kualitas produk, harga, promosi dan tempat pendistribusian terhadap keputusan pembelian sepeda motor Yamaha pada CV Tjahaja Baru Bukit tinggi, 1(1), 68-82.

Tjiptono, F. (2011). Strategi Pemasaran. Yogyakarta: Andi Offset.

Trisnawan, A.D. dan Amron. (2014). Ekonomi dan Bisnis. Pengaruh kualitas produk,harga, promosi dan distribusi terhadap loyalitas konsumen handphone Samsung di Semarang, 1-12.

Umam, K. dan Susanto, R. dan Purba, I.S. (2014). Pengantar Bisnis. Jakarta : Mitra Wacana Media.

Widodo, U. (2020). Fokus ekonomi. Pengaruh kualitas produk, harga, merek dan saluran distribusi terhadap volume penjualan pada PT. Gelang Gemilang Jaya Bella Spring Bed Semarang, 15(1), 217-230. 